\title{
PENERAPAN MODEL INKUIRI TERBIMBING TERHADAP KEMAMPUAN BERPIKIR KRITIS PESERTA DIDIK DI SMA NEGERI 2 MAJENE
}

\author{
Muhdana'), Herman'), dan Kaharuddin Arafah' \\ 1, 2,3)Prodi Pendidikan Fisika, Universitas Negeri Makassar, Indonesia \\ Jl. Daeng Tata Raya, Kampus Parangtambung, 90233 Makassar, Indonesia \\ 1)email: muhdana.physic@gmail.com
}

\begin{abstract}
Abstrak. Penelitian ini merupakan penelitian true eksperiment dengan desain posttest only control group design. Penelitian ini bertujuan untuk mendeskripsikan kemampuan berpikir kritis serta untuk menganalisis perbedaan kemampuan berpikir kritis peserta didik pada kelas eksperimen dan kelas kontrol. Penelitian ini dilaksanakan di SMA Negeri 2 Majene Tahun Ajaran 2018/2019 dengan sampel yaitu kelas XI MIA 1 yang berjumlah 31 orang sebagai kelas eksperimen dan kelas XI MIA 3 sebanyak 31 orang sebagai kelas kontrol. Pemilihan sampel dilakukan secara acak. Pada kelas eksperimen diterapkan pembelajaran inkuiri terbimbing dan kelas kontrol diterapkan pembelajaran secara konvensional. Hasil tes uji statistik deskriptif kemampuan berpikir kritis diperoleh skor ratarata pada kelas eksperimen yaitu 14,10 dengan kategori tinggi, sedangkan pada kelas kontrol skor rata-rata yaitu 8,52 dengan kategori sedang dari skor ideal 21. Hasil uji statistik menggunakan uji t diperoleh bahwa $\mathrm{H}_{0}$ ditolak dan $\mathrm{H}_{1}$ diterima. Dengan demikian dapat disimpulkan bahwa terdapat perbedaan kemampuan berpikir kritis antara peserta didik yang diajar dengan pembelajaran inkuiri terbimbing dengan yang diajar secara konvensional.
\end{abstract}

Kata kunci: pembelajaran inkuiri terbimbing, kemampuan berpikir kritis

\begin{abstract}
The Application of Guiede Inquiry Model to the ability of Student Critical Thinking in SMA Negeri 2 Majene. This research was true-experiment research that using posttest-only control group design. The aims of this study was to describe critical thinking skill which is taught by using Guided Inquiry learning and conventional learning, and to analyze the differences in critical thinking skill of students between the control class and experimental class. The study was conducted at SMA Negeri 2 Majene academic year 2018/2019 with sample are class X MIPA 1 which amounted to 31 students as experiment class and X MIPA 3 as many 31 students as control class. In the experimental class applied the guided inquiry learning and the control class applied the conventional learning. The results of critical thinking skill test in experimental class obtained average score of 14,10 in high category, while in control class the average score is 8,52 with medium category from ideal score 21. Based on inferential statistic using t-test obtained that Ho was rejected so $H_{l}$ was accepted. Thus, it can be concluded that there are differences of critical thinking skill between students who studied thorough guided inquiry learning rather than conventional learning.
\end{abstract}

Keywords: guided inquiry learning, critical thinking skills

\section{PENDAHULUAN}

Pendidikan merupakan suatu bentuk usaha dalam meningkatkan kualitas kehidupan manusia, yaitu dalam peranannya untuk memanusiakan manusia. Salah satu upaya pemerintah dalam meningkatkan mutu Pendidikan yaitu dengan menuntut pendidik memiliki 4 kompetensi yang wajib dikuasai guru yaitu kompetensi pedagogik, professional, sosial dan kepribadian. Dalam kompetensi pedagogik guru diharapkan mampu menerapkan strategi yang cocok dengan mencapai pembelajaran yang aktif, inovatif, kratif, efektif dan menyenangkan agar siswa dapat memahami materi yang disampaikan dalam pembelajaran fisika. mencakup komponen: mengamati, menanya, mencoba, mengolah, menyajikan, menyimpulkan, dan mencipta

Pembelajaran fisika merupakan rumpun ilmu pengetahuan alam (IPA) dengan tujuan mengembangkan kemampuan berpikir kritis, induktif, dan deduktif, berdasarkan konsep dan prinsip fisika. Dengan demikian pembelajaran fisika diharapkan tidak hanya dengan menganut sistem konsep dan materi saja namun perlu menekankan pada kemampuan khusus yang berguna untuk menghadapi permasalahan dalam 
kehidupan nyata, seperti kemampuan berpikir tingkat tinggi atau berpikir kritis.

Kemampuan berpikir kritis dapat menjadi penentu kemampuan siswa dalam menjelaskan permasalahan pada saat mengikuti pembelajaran.

Kemampuan berpikir kritis tidak hanya berguna untuk menunjang akademik siswa, namun berguna juga dalam menghadapi tantangan serta masalah kehidupan dimasa mendatang. Siswa perlu mengembangkan kemampuan berpikir kritis dalam kehidupan sehari-hari, dengan berpikir kritis ketika siswa dihadapkan pada suatu masalah dalam kesehariannya, sehingga siswa dapat menentukan/memikirkan berbagai solusi yang tepat, meskipun siswa tersebut tidak melanjutkan pendidikan ke jenjang yang lebih tinggi, kemampuan berpikir kritis siswa dapat membentuk mereka menemukan solusi atas berbagai masalah yang dihadapi.

Hasil observasi peneliti di SMA Negeri 2 Majene, peneliti memperoleh informasi bahwa guru belum secara spesifik/memperhatikan kemampuan berpikir kritis dalam pembelajaran dan pada saat pemberian latihan soal, guru terlebih dahulu memberikan contoh soal dimana dalam latihan itu, untuk menjawabnya sangat mudah karena hanya menggunakan rumus rumus yang sudah tersedia pada bahan ajar. Sehingga menyebabkan peserta didik hanya menghapal rumus tanpa mengetahui konsep fisika yang sebenarnya. Peserta didik hanya menyerap informasi secara pasif dan kemudian mengingatnya pada saat mengikuti tes. Guru juga mengungkapkan bahwa dalam mengetahui sikap psikomotorik peserta didik hanya dengan melihat siapa yang aktif bertanya dalam kelas dan hanya sebagian kecil saja yang jika dikasih kesempatan untuk bertanya, kebanyakan mereka hanya diam, dan satu dua orang saja yang bertanya.

Untuk praktiknya berdasarkan informasi dari peserta didik, jarang dan mereka belum familiar seperti merumuskan masalah, menyusun hipotesis merangkai alat, menganalisis data dan membuat kesimpulan. Karena jika mereka melakukan praktikum mereka tidak menggunakan LKPD (lembar kerja peserta didik) tapi mereka hanya memperhatikan simulasi yang dipraktikan oleh gurunya dan hasil praktikumnya hanya dengan menyimpulkan apa yang bisa mereka dapatkan dari praktikum. Disekolah tersebut sangat memungkinkan untuk melakukan praktikum karena disekolah tersebut sudah mempunyai laboratorium fisika dan alat-alat yang ada di lab sangat memadai untuk melakukan praktikum dan kebanyakan dari peserta didik mengatakan bahwa mereka senang melakukan praktikum dan mereka ingin tahu alat-alat yang ada dalam laboratorium itu. Pendekatan pembelajaran yang dapat memberikan bekal bagi siswa untuk dapat memahami dan mengaplikasikan konsep-konsep dasar fisika serta meningkatkan kemampuan berpikir kritis peserta didik adalah model inkuiri terbimbing.

Menurut Dewi (2013) model pembelajaran inkuiri terbimbing menekankan pada proses penemuan sebuah konsep sehingga muncul sikap ilmiah pada diri siswa dan dapat dirancang penggunaanya oleh guru menurut tingkat perkembangan intelektual siswa. Penerapan model pembelajaran inkuiri terbimbing ini dapat meningkatkan pemahaman siswa terhadap materi yang sedang dipelajari, Karena siswa mencari dan menemukan sendiri informasi tentang materi tersebut.

Sistem pembelajaran yang memberi kesempatan kepada siswa untuk aktif melakukan kegiatan dalam proses belajar mengajar dan menyebabkan siswa termotivasi untuk mempelajari suatu materi pembelajaran sehingga apa yang diperoleh siswa dari belajar akan memperpanjang daya ingat dari pada daya menghafal. Oleh karena itu, menarik untuk dilakukan dengan menggunakan metode pembelajaran yang mudah dipahami, 
menyenangkan, dan menarik perhatian siswa untuk menggali sumber belajar lebih jauh yakni dengan metode pembelajaran inkuiri terbimbing. Metode pembelajaran inkuiri merupakan metode yang mempersiapkan peserta didik pada situasi untuk melakukan eksperimen sendiri secara luas agar melihat apa yang terjadi, ingin melakukan sesuatu, mengajukan pertanyaan-pertanyaan, dan mencari jawabannya sendiri.

Berdasarkan hasil penelitian dari beberapa peneliti tentang model pembelajaran inkuiri terbimbing untuk meningkatkan kemampuan berpikir kritis peserta didik sudah cukup efektif. Hasil penelitian Rasulun I, dkk (2017), dengan judul meningkatkan kemampuan berpikir kritis siswa dengan model inkuiri terbimbing pada materi pesawat sederhana di SMP Negeri 9 Banda Aceh yaitu kemampuan berpikir kritis siswa yang diajarkan dengan metode inkuiri terbimbing adalah terdapat peningkatan yang signifikan kemampuan berpikir kritis peserta didik yang setelah diajar menggunakan metode inkuiri terbimbing. Begitu juga hasil penelitian Nisa, E, dkk (2018) yang berjudul development of guided inquiry-based physics teaching materials to increase criticak thinking skills of highschool students, hasil penelitiannya menyimpulkan bahwa bahan ajar fisika berbasis inkuiri terbimbing layak digunakan dalam pembelajaran serta dapat meningkatkan keterampilan berpikir kritis siswa SMA. Pada penelitian Azizah, dkk (2010) dengan judul pengaruh model pembelajaran inkuiri terbimbing terhadap kemampuan berpikir kritis siswa pada materi energi bunyi, hasil penelitiannya menyimpulkan bahwa model pembelajaran inkuiri terbimbing dapat meningkatkan kemampuan berpikir kritis siswa pada materi energi bunyi secara signifikan.

Berdasarkan pemaparan yang telah diuraikan tersebut, peneliti akan melakukan penelitian untuk

kemudian dianalisis dengan uji statistik deskriptif dan uji statisik inferensial. mengkaji "Penerapan Model Inkuiri Terbimbing Terhadap Kemampuan Berpikir Kritis Peserta Didik di SMA Negeri 2 Majene Tahun Pelajaran 2018/2019". Rumusan masalah dalam penelitian adalah Bagaimana deskripsi kemampuan berpikir kritis peserta didik kelas XI SMA Negeri 2 Majene yang diajar dengan menggunakan model pembelajaran inkuiri terbimbing dan yang diajar dengan pembelajaran konvensional, dan Apakah terdapat perbedaan kemampuan berpikir kritis peserta didik kelas XI SMA Negeri 2 Majene yang diajar dengan menggunakan model pembelajaran inkuiri terbimbing dan yang diajar dengan pembelajaran konvensional?

\section{METODE}

Penelitian ini merupakan penelitian eksperimen sesungguhnya (true experimental research). Sampel dalam penelitian ini adalah kelas XI MIPA 1 sebagai kelas eksperimen dan kelas XI MIA 3 sebagai kelas kontrol dengan jumlah peserta didik masing-masing 31 orang.. Instrument penelitian yang digunakan adalah instrumen tes kemampuan berpikir kritis peserta didik dalam bentuk pilihan ganda. Kemampuan berpikir kritis yang dimaksud memuat indikator yaitu interpetasi, analisis dan inferensi, setiap indikator terdiri dari 7 soal, dengan total soal sebanyak 24 buir soal.

Teknik pengumpulan data yang digunakan yaitu dalam bentuk kegiatan evaluasi diakhir pembelajaran. Adapun data yang diperoleh yakni data skor hasil tes kemampuan berpikir kritis peserta didik. Data ini dimaksudkan untuk melihat perbedaan kemampuan berpikir kritis peserta didik yang diajar dengan menggunakan pembelajaran inkuiri terbimbing pada kelas eksperimen dan yang diajar secara konvensional pada kelas kontrol. Data-data yang diperoleh

\section{HASIL DAN PEMBAHASAN}


HASIL

Adapun data distribusi frekuensi dan pengkategorian skor kemampuan berpikir kritis peserta didik SMA Negeri 2 Majene pada kelas eksperimen dan kelas kontrol dapat dilihat pada tabel 1 .

Tabel 1. Distribusi Frekuensi dan Pengkategorian Kemampuan Berpikir Kritis Peserta Didik Pada Kelas Eksperimen dan Kelas Kontrol

\begin{tabular}{cccccc}
\hline \multirow{2}{*}{$\begin{array}{c}\text { Interval } \\
\text { Kelas }\end{array}$} & Kategori & \multicolumn{2}{c}{ Kelas Eksperimen } & \multicolumn{2}{c}{ Kelas Kontrol } \\
\cline { 3 - 6 } & & Frekuensi & $\begin{array}{c}\text { Persentase } \\
(\%)\end{array}$ & Frekuensi & $\begin{array}{c}\text { Persentase } \\
(\%)\end{array}$ \\
\hline $16 \leq \mathrm{X}<21$ & Sangat tinggi & 8 & 25,81 & 0 & 0,00 \\
$12 \leq \mathrm{X}<16$ & Tinggi & 18 & 58,06 & 3 & 9,68 \\
$8 \leq \mathrm{X}<12$ & Sedang & 5 & 16,13 & 17 & 54,84 \\
$4 \leq \mathrm{X}<8$ & Rendah & 0 & 0,00 & 11 & 35,48 \\
$0 \leq \mathrm{X}<4$ & Sangat rendah & 0 & 0,00 & 0 & 0,00 \\
\hline \multicolumn{2}{c}{ Jumlah } & 31 & 100,00 & 31 & 100,00 \\
\hline
\end{tabular}

Tabel 1. Menunjukan bahwa kemampuan berpikir kritis peserta didik pada kelas eksperimen berada pada kategori tinggi dengan persentase yaitu $58,06 \%$ sedangkan pada kelas kontrol kemampuan berpikir kritis peserta didik berada pada kategori sedang dengan persentase 54,84\%. Hal ini menunjukan bahwa kemampuan berpikir kritis kelas eksperimen lebih baik dibandingkan dengan kelas kontrol.

Adapun persentase skor kemampuan berpikir kritis peserta didik pada kelas eksperimen dan kelas konrol berdasarkan pengkategorian melalui analisis deskriptif, data dilihat pada diagram berikut.

Gambar 1. Diagram persentase nilai kemmapuan berpikir kritis peserta didik kelas eksperimen dan kelas kontrol berdasarkan distrbusi frekuensi.

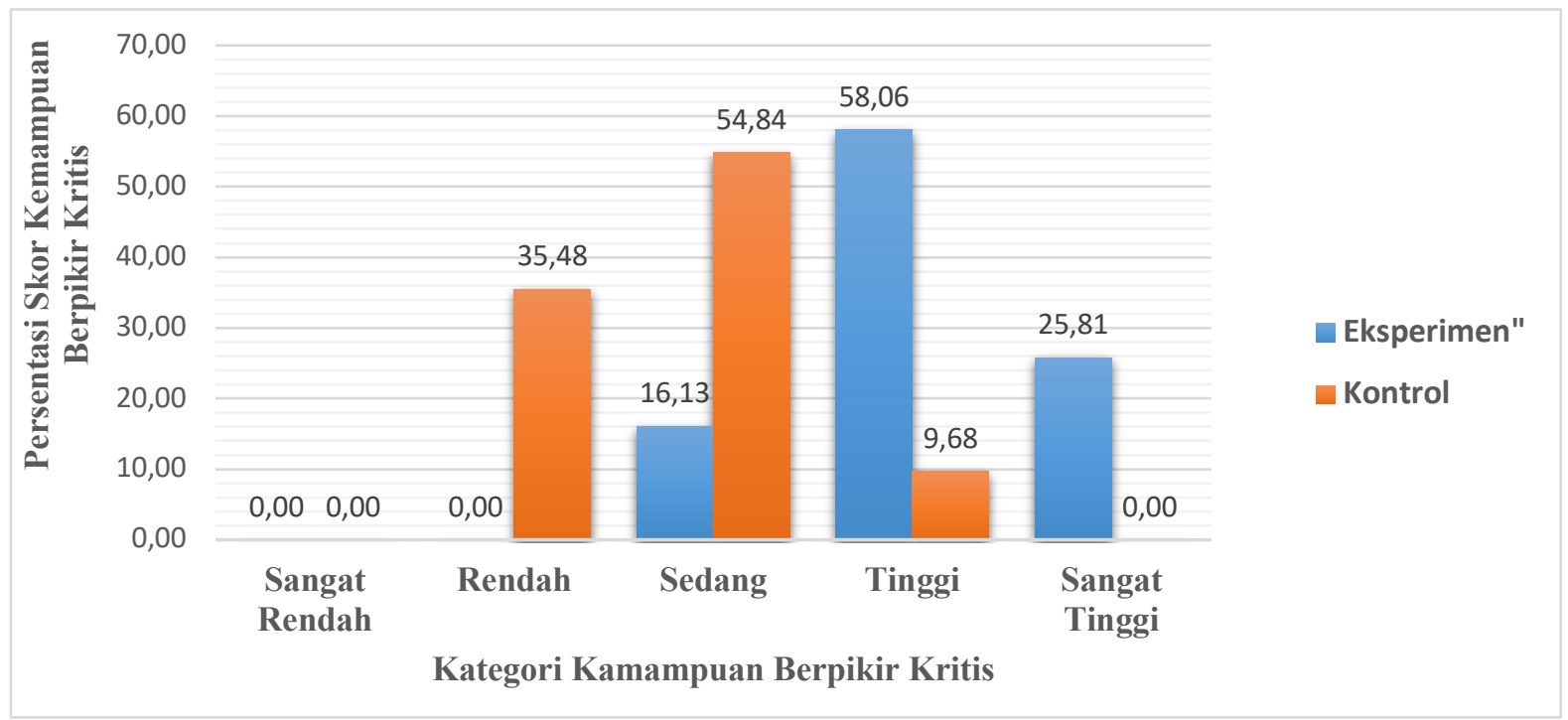


Perolehan skor rata-rata untuk ketiga indikator kemampuan berpikir kritis peserta didik pada kelas eksperimen dan kelas kontrol yakni interpretasi, analisis dan inferensi ditampilkan pada diagram berikut.

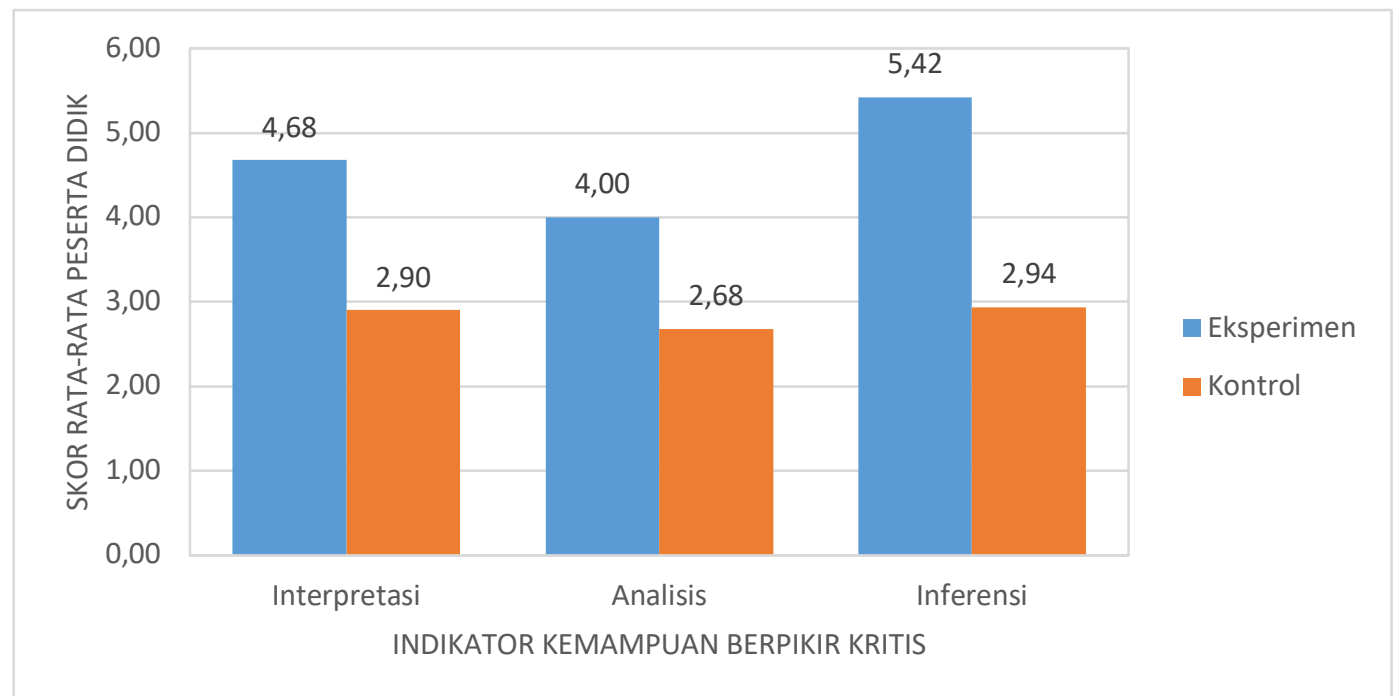

Gambar 2. Diagram Skor Rata-Rata Kemampuan Berpikir Kritis Peserta Didik pada Kelas Eksperimen Dan Kelas Kontrol

\section{PEMBAHASAN}

Penelitian ini dilaksanakan di SMA Negeri 2 Majene tahun akademik 2018/2019 dengan populasi seluruh peserta didik kelas XI MIA yang berjumlah 154 orang, dan yang menjadi sampel pada penelitian ini adalah kelas XI MIA 1 sebagai kelas eksperimen dan XI MIPA 3 sebagai kelas kontrol. Penelitian ini bertujuan untuk mengetahui perbedaan kemampuan berpikir kritis antara peserta didik yang diajar dengan menggunakan model pembelajaran inkuiri terbimbing dengan peserta didik yang diajar dengan menggunakan pembelajaran konvensional.

Pelaksanaan pembelajaran pada kelas eksperimen untuk pertemuan pertama peneliti memberikan sebuah masalah, kemudian siswa mengajukan hipotesis beragam. Untuk memastikan jawaban mereka benar atau tidak peneliti memberikan sebuah lembar kerja peserta didik (LKPD).

Pelaksanaan pembelajaran berbasis inkuiri terbimbing dilakukan dengan pemberian masalah kepada peserta didik dalam bentuk lembar kerja fisika, Alur pembelajaran disesuaikan dengan enam tahapan pembelajaran inkuiri terbimbing yakni 1) mengorientasikan/menghadapkan peserta didik pada masalah, pada tahap ini guru menyajikan masalah di bagian awal Lembar kerja peserta didik (LKPD), Untuk memastikan masalah yang disajikan dimengerti oleh semua peserta didik, maka digunakan lembar kerja peserta didik dilengkapi dengan gambar ilustrasi untuk menampilkan masalah, 2) menyusun hipotesis, pada tahap ini guru membimbing perserta didik untuk menemukan jawaban sementara/hipotesis dari permasalahan yang ada pada LKPD, Sehingga secara berkelompok peserta didik mencari dan menemukan jawaban permasalahan, 3) menyiapkan/merancang percobaan percobaan, pada tahap ini peserta didik merangkai alat dengan melihat lembar kerja serta bimbingan dari guru, 4) mengumpulkan data dalam kegiatan, peserta didik menjawab pertanyaan dan melakukan kegiatan penyelidikan yang disajikan di dalam LKPD, Selama kegiatan berlangsung, guru membimbing untuk memastikan semua kelompok aktif melakukan penyelidikan, 5) menganalisis data dalam 
penelitian, peserta didik menganalisis data berdasarkan pertanyaan pada lembar kerja peserta didik, setiap perwakilan kelompok akan menyajikan hasil temuan yang diperoleh berupa jawaban dari permasalahan, Setelah itu, guru memberikan kesempatan kepada semua peserta didik untuk memberikan tanggapan terhadap hasil diskusi kelompok tersebut, 6) menyimpulkan dan mengevaluasi proses pemecahan masalah, dalam tahapan ini guru mengoreksi hasil diskusi kelompok jika terdapat kekeliruan.

Pelaksanaan pembelajaran kelas kontrol pada pertemuan pertama, guru memberikan langsung penjelasan mengenai materi yang dipelajari tanpa memberikan masalah terlebih dahulu, hal ini mengakibatkan siswa tidak terbiasa dengan masalah. Pembelajaran pada kelas kontrol lebih berpusat pada guru, padahal seharusnya berpusat pada siswa dan siswa diharuskan lebih aktif untuk mencari sendiri materi yang sedang dipelajari.

\section{Kemampuan Berpikir Kritis}

Merujuk pada pengaktegorian skor pada tabel 1. untuk kelas eksperimen skor rata-rata kemampuan berpikir kritis peserta didik berada pada kategori tinggi, sedangkan untuk kelas kontrol skor rata-rata kemampuan berpikir kritis peserta didik berada pada kategori sedang. Sehingga dapat disimpulkan bahwa skor rata-rata kemampuan berpikir kritis peserta didik yang diajar dengan pembelajaran inkuiri terbimbing berada pada kategori tinggi dan skor kemampuan berpikir kritis peserta didik yang diajar secara konvensional berada pada kategori sedang. Hal ini menunjukan bahwa kemampuan berpikir kritis peserta didik kelas eksperimen berbeda dibandingkan kelas kontrol. Hasil penelitian ini sesuai dengan penelitian yang telah dilakukan Agustin, dkk (2014) dalam penelitiannya menyatakan bahwa model pembelajaran inkuiri terbimbing lebih baik daripada kelas yang menggunakan pembelajaran konvensioanal.
Hasil analisis deskriptif untuk tiap indikator, berdasarkan gambar 2. pada kelas eksperimen untuk indikator interpretasi diperoleh skor ratarata sebesar 4,68 dan untuk indikator analisis diperoleh skor rata-rata sebesar 4,00 sedangkan untuk indikator inferensi diperoleh skor rata-rata sebesar 5,42 sedangkan untuk kelas kontrol untuk indikator interpretasi diperoleh skor rata-rata sebesar 2,90 dan untuk indikator analisis diperoleh skor rata-rata sebesar 2,68 sedangkan untuk indikator inferensi diperoleh skor rata-rata sebesar 2,94. Sehingga dapat disimpulkan bahwa kemampuan berpikir kritis peserta didik yang diajar dengan pembelajaran inkuiri terbimbing berbeda secara signifikan daripada siswa yang diajar dengan pembelajaran secara konvensional. Hal ini sama dengan hasil penelitian Yeritia, dkk (2017) yang menyatakan bahwa skor rata-rata tiap indikator kemampuan berpikir kritis untuk kelas eksperimen lebih tinggi daripada kelas kontrol.

Proses pembelajaran dengan menggunakan pembelajaran inkuiri terbimbing berbeda dibandingkan dengan pembelajaran secara konvensional karena pada proses pembelajaran inkuiri terbimbing menyediakan tahap pembelajaran dilakukan secara individu dan berkelompok, sehingga terjadi pertukaran informasi untuk menyelesaikan masalah yang diajukan oleh guru. Hal ini menyebabkan siswa dapat berpikir luas dan belajar dari pengalaman (melaksanakan percobaan) serta belajar dari teman mengenai konsep yang sedang dipelajari. Dengan demikian, proses pembelajaran dengan menggunakan model pembelajaran terbimbing sesuai dengan teori Piaget (Sanjaya, 2006:194), "pengetahuan itu akan bermakna manakala dicari dan ditemukan sendiri oleh siswa". Hal ini tercermin dari respon siswa yang antusias ketika mereka mengajukan hipotesis, sehingga terkesan berebut ingin pertama mengungkapkan, semangat karena mereka bekerja secara berkelompok, merasa tertantang untuk membuktikan hipotesis 
masing-masing, sehingga dapat menjawab pertanyaan-pertanyaan yang diajukan guru. Selain itu, kegiatan menyusun sendiri alat dan bahan. Langkah kerja, dan melaksanakan percobaan secara mandiri yang dilakukan di kelas eksperimen dilakukan untuk mengungkap alternatif-alternatif yang dimiliki siswa dalam memecahkan masalah.

Kemampuan berpikir kritis peserta didik setelah diajar dengan pembelajaran inkuiri terbimbing berbeda dengan kemampuan berpikir krtitis peserta didik setelah diajar dengan pembelajaran konvensional karena pada pembelajaran inkuiri terbimbing memposisikan siswa untuk menyelesaikan permasalahan yang diajukan guru melalui pengajuan hipotesis, pengumpulan data, pengujian hipotesis melalui data yang dikumpulkan, sehingga pada tahap akhir siswa dapat menarik kesimpulan dari proses pembelajaran yang telah dilaksanakan. Kelebihan pada inkuiri terbimbing terletak pada tahap-tahap pelaksanaan pembelajarannya dimana pada tahaptahap pembalajarannya melatih siswa dalam meyelesaikan masalah sampai dengan merumuskan kesimpulan sehingga kemampuan berpikir kritis siswa kelas eksperimen berbeda dengan kemampuan berpikir kritis kelas kontrol pada indikator inferensi, analisis dan interpretasi dimana pada indikator tersebut menuntut siswa untuk dapat menyelesaikan masalah dan menarik kesimpulan. Begitu juga pada penelitian Wahyuni (2018), dalam penelitiannya yang berjudul penerapan model pembelajaran inkuiri terbimbing dalam meningkatkan kemampuan berpikir kritis pada pembelajaran fisika, hasil penelitiannya menyimpulakan bahwa model inkuiri terbimbing berpegaruh signifikan terhadap keterampilan berpikir kritis fisika siswa kelas X di SMA Negeri 3 Padangsidimpuang.

\section{Pengujian Hipotesis}

Hasil perhitungan analisis inferensial menunjukkan bahwa skor kemampuan berpikir kritis peserta didik kelas eksperimen dan kelas kontrol terdistribusi normal dan memiliki varian yang homogen sehingga prasyarat penggunaan uji-t terpenuhi, diperoleh nilai $t_{\text {hitung }}$ sebesar 9,72 sedangan nilai $t_{\text {tabel }}$ adalah sebesar 2,00. Dari hasil tersebut dapat terlihat bahwa $t_{\text {hitung }}>t_{\text {tabel }}$, sehingga $\mathrm{H}_{0}$ ditolak dan $\mathrm{H}_{1}$ diterima. Dengan demikian maka dapat disimpulkan bahwa terdapat perbedaan kemampuan berpikir kritis antara peserta didik yang diajar dengan pembelajaran inkuiri terbimbing dan yang diajar secara konvensional, dimana terlihat bahwa skor ratarata kelas eksperimen lebih tinggi dibandingkan dengan skor rata-rata kelas kontrol. Hal ini dapat di akibatkan oleh pelaksanaan pembelajaran yang dilaksanakan dikelas kontrol, setelah melihat rencana pelaksanaan pembelajaran guru pelaksanaan pembelajaran yang dilakukan di kelas, tidak dilakukan praktikum padahal pada RPP yang di buat guru menggunakan model pembelajaran berbasis masalah dengan empat pertemuan yang setiap pertemuannya melakukan praktikum. Adanya ketidaksesuaian perangkat pembelajaran dengan model pembelajaran di kelas menjadi penyebab kurang efektifnya pembelajaran pada kelas kontrol.

\section{KESIMPULAN}

Berdasarkan hasil analisis data tersebut maka dapat disimpulkan yaitu: (1) Skor kemampuan berpikir kritis peserta didik yang diajar dengan pembelajaran inkuiri terbimbing berada pada kategori tinggi, (2) skor kemampuan berpikir kritis peserta didik yang diajar secara konvensional berada pada kategori sedang, (3) terdapat perbedaan kemampuan berpikir kritis antara peserta didik yang diajar dengan pembelajaran inkuiri terbimbing dan yang diajar secara konvensional.

\section{REFERENSI}


Agustin, R. S. (2014). Penerapan Model Pembelajaran Inkuiri terbimbig Unuk Melatihkan Kemampuan Keterampilan Berpikir Kritis Siswa Kelas XI SMAN 1 Kalianget. . Inovasi Pendidkan Fisika, 3(2), 14-19.

Azizah, A. K. (2010). Pengaruh Model Pembelajaran Inkuiri Terbimbing Terhadap Kemampuan Berpikir Kritis Siswa Pada Materi Energi Bunyi . Pena Ilmiah, 1(1), 1-10.

Dewi, L. (2013). Pengaruh Model Pembelajaran Inkuiri Terbimbing Terhadap Sikap Ilmiah Dasar Dan Hasil Belajar IPA. Pendidikan Dasar, 3(1), 1-10.

Nisa, E. J. K. (2018). Development Of Guided Inquiry-Based Physics Teaching Materials To Increase Criticak Thinking
Skills Of Highschool Students. Pendidikan Fisika Indonesia. 14(1), 1825.

Sanjaya, W. (2006). Strategi pembelajaran Berorientasi Standar Proses Pendidikan. Jakarta: Kencana

Wahyuni, S. (2018). Penerapan Model Inkuiri Terbimbing (Guided Inkuiry) dalam Meningkatkan kemampuan Berpikir Kritis pada Pembelajaran Fisika. Education and Development, 3(1), 1-5

Yerita, S. W. S (2017). Penerapan Model Pembelajaran Inkuiri terbimbing Terhadap Penguasaan Konsep dan kemampuan berpikir Kritis Fisika Peserta Didik Kelas X SMAN 1 Kuripan Tahun ajaran 2017/2018. Pendidikan Fisika dan Tekhnologi, 3(2), 1-7 